\title{
INDEKS PERTUMBUHAN IKAN KAKAP MERAH DAN KERAPU LUMPUR PADA PERIKANAN BUBU DASAR DI PERAIRAN BUNYU
}

\section{INDEX GROWTH OF Lutjanus argentimaculatus AND Epinephalus malabaricus BOTTOM FISH POTS FISHERIES AT BUNYU WATERS}

\author{
Muhammad Firdaus ${ }^{1}$, Gazali Salim ${ }^{1}$, Jimmy Cahyadi ${ }^{2}$, Encik Weliyadi $^{1}$ \\ ${ }^{1}$ Program Studi Manajemen Sumberdaya Perairan, \\ ${ }^{2}$ Program Studi Akuakultur, \\ Fakultas Perikanan dan Ilmu Kelautan, Universitas Borneo Tarakan \\ Korespondensi: dayax2302@yahoo.com
}

\begin{abstract}
Bunyu Island in the North Kalimantan province has abundant and economically valuable marine aquatic ecosystem resources, where Bunyu Island communities utilize the potential of marine aquatic ecosystems to be used as fishery potential in terms of fishing using bottom fish pots. Fishing catch is economically valuable in the form of red snapper and grouper fish found in the marine ecosystems of Bunyu Island. The research objective was to analyze the growth and size structure of the Red Snapper fish (Lutjanus argentimaculatus) and Grouper fish (Epinephalus malabaricus) originating from the waters of the island of Bunyu. Retrieval of data in the form of growth parameters are the total length and standard length, total weight, gender, gonad maturity level, and gonad weight. The results of the study of most snapper caught the length of 40,49-47,61 cm and a weight of 990,05-1.451,68 grams. While the results of the grouper study most caught were 43,73-50,13 cm in length and weights of $800,94-1.308,70$ grams. The nature of growth of Red Snapper fish (Lutjanus argentimaculatus) are negative allometry. The condition index value is skinny of Red Snapper fish (Lutjanus argentimaculatus). Grouper fish (Epinephalus malabaricus) of total length and total weight is positive allometry and on the standart and fork length with total weight is negative allometri.
\end{abstract}

Keywords: condition factor, grouper, length-weight relationship, red snapper

\begin{abstract}
ABSTRAK
Pulau Bunyu di Propinsi Kalimantan Utara memiliki sumberdaya hayati ekosistem perairan laut yang berlimpah dan bernilai ekonomis yang tinggi, dimana masyarakat pulau Bunyu memanfaatkan potensi ekosistem perairan laut digunakan sebagai potensi perikanan dalam hal penangkapan dengan menggunakan alat tangkap bubu dasar (bottom fish pot). Hasil tangkapan yang bernilai ekonomis berupa ikan kakap merah dan ikan kerapu yang terdapat di perairan ekosistem laut pulau Bunyu. Tujuan penelitian adalah menganalisis pertumbuhan dan struktur ukuran ikan kakap merah (Lutjanus argentimaculatus) serta ikan kerapu lumpur (Epinephalus malabaricus) yang berasal dari perairan pulau Bunyu. Data yang diteliti berupa parameter pertumbuhan yaitu panjang total dan panjang standar, berat total, jenis kelamin, tingkat kematangan gonad, dan berat gonad. Hasil penelitian ikan kakap paling banyak tertangkap ukuran panjang 40,49-47,61 cm dan bobot 990,05-1.451,68 gram. Pada ikan kerapu lumpur dengan ukuran panjang 43,73$50,13 \mathrm{~cm}$ dan berat 800,94-1.308,70 gram. Sifat pertumbuhan pada ikan kakap merah adalah allometrik negatif. Nilai indeks kondisi berbentuk kurus pada sampel ikan kakap merah. Sifat pertumbuhan pada sampel ikan kerapu pada variabel panjang total dengan berat total bersifat allometrik positif dan pada variabel panjang standar dan panjang cagak dengan berat total bersifat allometrik negatif.
\end{abstract}

Kata kunci: faktor kondisi, hubungan panjang berat, ikan kakap, ikan kerapu 


\section{PENDAHULUAN}

Pulau Bunyu secara administrasi merupakan daerah/wilayah bagian dari Kabupaten Bulungan Propinsi Kalimantan Utara dimana memiliki wilayah yang memiliki lingkungan wilayah perairan laut mengelilingi pulau Bunyu. Pulau Bunyu secara ekologi merupakan wilayah kepulauan yang memiliki sumberdaya hayati laut yang bernilai ekonomis cukup tinggi dikarenakan terdapat berbagai ekosistem yaitu ekosistem pantai, ekosistem mangrove, ekosistem terumbu karang, ekosistem padang lamun, dan ekosistem perairan laut. Ekosistem perairan laut merupakan ekosistem yang dijadikan sebagai salah satu target ekonomis cukup tinggi dalam memanfaatkan dan menggali potensi sumberdaya hayati laut. Sumberdaya hayati perikanan yang terdapat di perairan ekosistem laut memiliki keanekaragaman berbagai biota perairan laut yang menjadi target untuk menaikkan perekonomian masyarakat di wilayah pulau Bunyu. Pemanfaatan sumberdaya tersebut dengan kegiatan perikanan tangkap di perairan Bunyu.

Kegiatan perikanan tangkap pada masyarakat di pulau Bunyu berdasarkan hasil wawancara menggunakan berbagai alat tangkap yaitu alat tangkap pukat hela, jaring insang hanyut, bagan, jermal/ togo, dan bubu dasar. Alat tangkap bubu dasar menurut Hatapayo (2004) bahwa alat tangkap bubu dasar sebagai alat tangkap ramah lingkungan yang bersifat pasif, dimana alat tangkap bubu merupakan alat tangkap menetap di dasar perairan yang bertujuan untuk menangkap ikan demersal. Jenis ikan demersal yang memiliki nilai ekonomis cukup tinggi, merupakan ikan yang sedang melakukan ruaya, antara lain jenis ikan kerapu lumpur (Epinephalus malabaricus) dan ikan kakap merah (Lutjanus argentimaculatus).

Hasil wawancara pendahuluan dengan nelayan yang ada di pulau Bunyu bahwa ikan target alat tangkap bubu dasar merupakan ikan yang bernilai ekspor dengan harga jual sebesar Rp 65.000 untuk harga ikan kakap merah per kilogram dan Rp 55.000 untuk harga per kilogram ikan kerapu lumpur. Pengoperasian alat tangkap bubu dilakukan dengan meletakkan bubu di dasar perairan lalu meninggalkannya selama beberapa hari (2-4 hari). Setelah itu dilakukan pengangkatan hasil tangkapan ikan. Alat tangkap bubu hanya bertahan selama kurang lebih 6 bulan karena terjadi pelapukan dimana alat tangkap bubu terbuat dari anyaman bambu. Salah satu faktor kelemahan dari alat tangkap bubu dasar yaitu apabila di laut terjadi hujan yang cukup deras ataupun terjadi arus bawah laut yang cukup kuat, maka bubu dasar dapat terbawa arus dan akan hilang. Selain itu, faktor kelemahan dari alat tangkap bubu ini adalah hasil tangkapan terbatas dikarenakan dimensi dari alat tangkap bubu yang memiliki panjang sekitar 2,5 meter dan lebar sekitar 1,5 meter. Nilai positif dari alat tangkap bubu ini adalah mudah dalam pengoperasian dan alat tangkap ikan target lebih mudah dibuat dengan bahan yang cukup tersedia.

Hasil tangkapan bubu dasar di perairan Bunyu adalah ikan demersal dengan nilai ekonomis penting, seperti ikan kakap merah dan ikan kerapu lumpur. Khusus ikan kakap merah (L. argentimaculatus) dan ikan kerapu lumpur (Epinephalus malabaricus) merupakan biota perairan yang dominan tertangkap pada bubu dasar di perairan Bunyu. Pengoperasian bubu dasar (bottom fish pots) menghasilkan tangkapan ikan demersal yang memiliki ragam spesies dan ukuran. Hal ini karena sifat biota tropis multi-spesies dan faktor teknis yang menyulitkan ikan untuk keluar lagi dari alat tangkap. Selain aneka-ragam ukuran (panjang dan berat), terindikasi juga beraneka-ragam kondisi biologi, antara lain pola pertumbuhan. Parameter pertumbuhan (model dan pola pertumbuhan) ikan kakap merah dan ikan kerapu lumpur, telah banyak diteliti di perairan Indonesia (Melianawati dan Andamari 2009; Sumiono et al. 2010; Wahyuningsih et al. 2013; dan Prihatiningsih et al. 2017). Namun untuk ikan kakap merah dan ikan kerapu di perairan Bunyu, belum tersedia data ilmiah tentang pertumbuhan dan struktur ukurannya.

Hubungan panjang berat kakap merah dan kerapu bersifat di perairan Barru Sulawesi Selatan menunjukkan pola/ sifat pertumbuhan allometrik positif (kakap merah, $b=3,13)$ dan allometrik negatif (kerapu lumpur, $\mathrm{b}=2,91$ ) (Sumiono et al. 2010). Menurut Smith (1991) dalam Nuraini (2007), nilai b yang valid pada ikan kerapu pada umumnya berkisar antara 2,5-3,5. Analisis terhadap lima jenis ikan kerapu di perairan Berau, Kalimantan Timur diperoleh nilai $\mathrm{b}$ yang berbeda, berkisar antara $b=2,488$ sampai $b=3,513$ (Sumiono 
et al. 2010). Ikan kakap merah di perairan Barru Sulawesi Selatan memiliki kisaran ukuran panjang 33,0-70,0 $\mathrm{cm}$ dan ukuran berat 400-4.900 gram dan pada ikan kerapu lumpur dengan kisaran panjang 39,0-72,0 $\mathrm{cm}$ dan ukuran berat 800-4.500 gram (Sumiono et al. 2010). Bagaimana dengan parameter pertumbuhan ikan kakap merah (Lutjanus argentimaculatus) di perairan Bunyu Kalimantan Utara? Tujuan penelitian ini untuk mendapatkan gambaran secara deskriptif kuantitatif mengenai model pertumbuhan berdasarkan sifat dan indeks populasi serta struktur ukuran mengenai ikan kakap merah dan ikan kerapu lumpur yang berasal dari perairan pulau Bunyu.

Nilai pertumbuhan adalah variabel biologi yang penting dalam pola pemanfaatan sumberdaya perikanan. Pengelolaan sumberdaya perikanan (perikanan tangkap), penting memperhatikan nilai biologi dalam pola pemanfaatan sumberdaya. Termasuk ikan kakap merah dan ikan kerapu lumpur di perairan Bunyu. Analisa indeks pertumbuhan bermanfaat pada penentuan selektivitas dalam pengelolaan perikanan tangkap (Mulfizar et al. 2012). Ditambahkan oleh Jennings et al. (2001) bahwa analisa pertumbuhan merupakan parameter yang sering dipelajari pada populasi ikan sebagai hal penting produktivitas stok sumberdaya ikan. Penelitian aspek biologi dengan pendekatan indeks pertumbuhan dan struktur umur ikan kakap merah (Lutjanus argentimaculatus) dan ikan kerapu lumpur (Epinephalus malabaricus) yang tertangkap di perairan Bunyu, bertujuan untuk mengamati tren aspek biologi serta penyediaan data aktual sebagai nilai penting pada pengelolaan lestari sumberdaya ikan kakap merah dan ikan kerapu lumpur.

\section{METODE PENELITIAN}

Penelitian dilaksanakan selama 4 bulan yaitu bulan Maret-Juni 2019 di perairan bagian selatan dan timur pulau Bunyu Kabupaten Bulungan Propinsi Kalimantan Utara. Pelaksanaan kegiatan penelitian dilaksanakan berdasarkan dari hasil tangkapan menggunakan alat tangkap nelayan bubu dasar (bottom trap) di daerah pulau Bunyu Kabupaten Bulungan Kalimantan Utara. Penentuan lokasi fishing ground alat tangkap bottom fish pot menggunakan metode purposive sampling, dimana daerah penentuan lokasi tersebut berdasarkan dengan habitat dan perjalanan ruaya ikan demersal yaitu ikan kerapu lumpur dan ikan kakap merah.

\section{Prosedur penelitian}

Penelitian mengenai model pertumbuhan berdasarkan sifat dan indeks serta struktur ukuran ikan kakap dan ikan kerapu yang berasal dari hasil tangkapan nelayan Bubu dasar (bottom fish pot) menggunakan metode deskriptif kuantitatif. Metode pengambilan sampel menggunakan alat tangkap bubu dasar menggunakan teknik purposive sampling, dimana sampel ikan yang didapatkan merupakan hasil tangkapan utama dari alat tangkap bubu dasar (bottom fish pot) yang bernilai ekonomis tinggi yaitu ikan kerapu lumpur dan ikan kakap merah. Analisis data pertumbuhan berupa sifat pertumbuhan serta struktur ukuran menggunakan pendekatan hubungan panjang-berat, faktor kondisi, dan struktur ukuran panjang dan berat.

Pengambilan sampel dilakukan dengan pendekatan survei di lapangan dan metode skala laboratorium. Metode survei di lapangan dilakukan dengan berperan aktif dalam kegiatan penangkapan menggunakan alat tangkap bubu dasar dengan pengulangan pengambilan sampel sebanyak 14 kali perulangan/trip. Hasil tangkapan bubu dasar sebagai sampel yaitu ikan kakap dan ikan kerapu, ditetapkan sebanyak masing-masing 3 ekor setiap trip, sehingga akan terkumpul total sampel sebanyak 84 ekor ikan. Hal ini ditentukan berdasarkan informasi nelayan bubu dasar di Pulau Bunyu bahwa nelayan umumnya menangkap ikan kakap/kerapu sebanyak 2-4 ekor per trip. Titik lokasi pengambilan data/sampel mengikuti nelayan bubu dasar. Nelayan di Pulau Bunyu mengoperasikan alat tangkap bubu dasar di perairan bagian selatan dan timur dari Pulau Bunyu. Waktu tempuh nelayan tiba di lokasi penangkapan (fishing ground) selama 30-45 menit. Pada lokasi sampling tersebut dilakukan perekaman titik koordinat menggunakan GPS dan pengukuran parameter lingkungan dari ikan kerapu lumpur dan ikan kakap merah.

Hasil tangkapan bubu dasar berupa ikan kerapu lumpur dan ikan kakap merah dijadikan sampel penelitian dalam pengamatan laboratorium. Uji lanjutan skala laboratorium dilakukan dengan pengamatan beberapa variabel 
sebagai kegiatan pengambilan data primer. Pengambilan data di laboratorium berupa parameter pertumbuhan yaitu panjang total dan panjang standar, berat total, jenis kelamin, tingkat kematangan gonad, dan berat gonad.

\section{Analisis data}

\section{Sifat pertumbuhan}

Sifat pertumbuhan dianalisis menggunakan pendekatan hubungan panjang berat rumus umum sebagai berikut:

$$
W=a L^{b}
$$

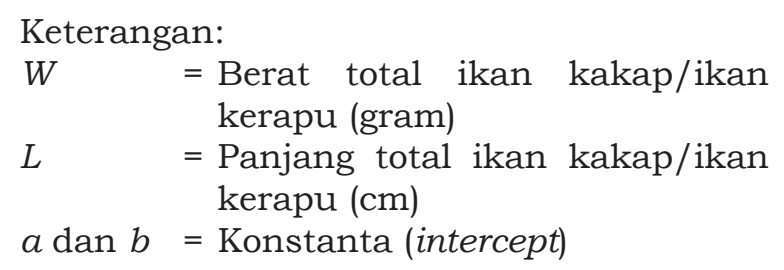

Pendekatan hubungan panjang-berat dalam mendeskripsikan sifat pertumbuhan diubah ke dalam bentuk logaritma sebagai formulasi/ persamaan linier atau garis lurus (Effendie 2002), yaitu:

$$
\log W=a+b \log L
$$

Hasil analisa hubungan panjangberat tersebut akan menjelaskan pertumbuhan ikan berdasarkan sifat populasi secara relatif. Nilai dari slope (b) akan menjadi perhatian dalam menggambarkan sifat pertumbuhan ikan. Apabila nilai slope $\mathrm{b}=3$ maka pertumbuhan ikan memiliki sifat pertumbuhan isometrik. Penjelasan pertumbuhan isometrik adalah model pertumbuhan yang memiliki pertambahan ukuran panjang dan ukuran berat pada ikan kerapu dan ikan kakap dengan kecepatan pertumbuhan yang sama/ proposional. Apabila nilai $\mathrm{b}>3$ atau $\mathrm{b}<3$, maka pertumbuhan ikan bersifat allometrik. Makna dari pertumbuhan allometrik adalah pertambahan ukuran panjang dan ukuran berat dengan kecepatan pertumbuhan yang tidak sama atau tidak proporsional. Sifat pertumbuhan allometrik positif terjadi jika nilai $\mathrm{b}>3$ (pertambahan ukuran berat lebih cepat dibandingkan dengan pertambahan ukuran panjang). Apabila nilai $\mathrm{b}<3$, maka sifat pertumbuhannya adalah allometrik negatif (pertambahan ukuran panjang lebih cepat dibandingkan dengan pertambahan ukuran berat) (Effendie 2002).

\section{Faktor kondisi}

Guna mengekspresikan bentuk tubuh secara detail dari informasi hubungan panjang berat (nilai koefisien b), menggunakan pendekatan nilai faktor kondisi Langler's (Effendie 2002). Faktor kondisi dengan sifat isometrik menggunakan rumus berdasarkan nilai $\mathrm{K}$ dalam sistem metrik dengan nilai $10^{5}$ sedemikian rupa hingga nilai $\mathrm{K}$ mendekati 1 , yaitu:

$$
K_{(T I)}=10^{5} \frac{W}{L^{3}}
$$

Keterangan:

$W=$ Berat total ikan kakap dan kerapu (gram)

$L \quad=$ Panjang total ikan kakap dan kerapu (mm)

$10^{5}=$ Rumus ini digunakan sehingga $K(T I)$ mendekati harga satu

Nilai faktor kondisi Le Cren's (Raeisi et al. 2011) untuk sifat pertumbuhan allometrik yaitu:

$$
K n=\frac{W}{\hat{W}}
$$

$W$ adalah berat ikan aktual (gram) dan $\hat{W}$ adalah berat ikan dugaan (gram) dari hasil $\log W=a+b * \log L$. Nilai $W$ (berat dalam gram) dan $L$ (panjang dalam $\mathrm{cm}$ ) merupakan nilai ukuran mutlak sampel ikan.

\section{Struktur ukuran panjang dan berat}

Pengujian mengenai struktur ukuran panjang dan berat pada ikan kakap merah dan ikan kerapu lumpur berdasarkan analisa distribusi ukuran dengan pendekatan nilai rentang kelas (nilai $K)$ dan interval kelas (i). Sajian data dalam menggambarkan struktur ukuran pada pengolahan data menggunakan metode deskriptif kuantitatif dengan sajian tabel dan gambar serta diagram pie.

\section{HASIL DAN PEMBAHASAN}

\section{Hasil penelitian}

\section{Struktur ukuran}

Hasil penelitian yang dilakukan selama kurang lebih 4 bulan, dimana dilakukan pengambilan sampel ikan kerapu 
dan kakap merah, didapatkan dengan jumlah total ikan kakap merah sebanyak 42 ekor dan ikan kerapu sebanyak 42 ekor. Hasil tangkapan menggunakan bubu untuk mendapatkan ikan kakap didapatkan ukuran terkecil yaitu ukuran $24,9 \mathrm{~cm}$ dan ukuran terpanjang yaitu ukuran $56 \mathrm{~cm}$. Hasil penelitian didapatkan rentang ukuran antara 24,9-56 $\mathrm{cm}$ dilakukan pengolahan data dengan membagi rentang kelas menjadi 5 bagian yaitu ukuran dengan panjang 24,9-29,27 cm sebanyak 3 ekor dengan persentase sebesar $7 \%$, ukuran dengan panjang 29,28-34,42 cm sebanyak 9 ekor dengan persentase sebesar $21 \%$, ukuran dengan panjang 34,43-40,48 $\mathrm{cm}$ sebanyak 10 ekor dengan persentase sebesar 24\%, ukuran dengan panjang 40,49-47,61 $\mathrm{cm}$ sebanyak 13 ekor dengan persentase sebesar $31 \%$ dan ukuran dengan panjang 47,62-56 cm dengan sebanyak 7 ekor dengan persentase sebesar 17\% (Gambar 1). Hasil tangkapan menggunakan bubu untuk mendapatkan ikan kakap didapatkan bobot terkecil sebesar 460,49 gram dan bobot terbesar pada berat 3.121,11 gram. Hasil penelitian didapatkan rentang berat antara 460,49-3.121,11 gram dilakukan pengolahan data dengan membagi rentang kelas menjadi 5 bagian yaitu rentang bobot kisaran 460,49-675,20 gram sebanyak 6 ekor dengan persentase sebesar 14\%, rentang bobot kisaran 675,21-990,04 gram sebanyak 11 ekor dengan persentase sebesar 26\%, rentang bobot kisaran 990,05$1.451,68$ gram sebanyak 12 ekor dengan persentase sebesar 29\%, rentang bobot kisaran 1.451,69-2.128,58 gram sebanyak 10 ekor dengan persentase sebesar $24 \%$ dan rentang bobot kisaran 2.128,59-3.121,11 gram sebanyak 3 ekor dengan persentase sebesar 7\% (Gambar 2).

Hasil tangkapan bubu untuk ikan kerapu didapatkan ukuran panjang terkecil yaitu ukuran $29 \mathrm{~cm}$ dan ukuran terpanjang yaitu ukuran $57,5 \mathrm{~cm}$. Hasil penelitian didapatkan rentang ukuran antara 29-57,5 $\mathrm{cm}$ dilakukan pengolahan data dengan membagi rentang kelas menjadi 5 bagian yaitu ukuran dengan panjang 29-33,24 cm sebanyak 2 ekor dengan persentase sebesar $5 \%$, ukuran dengan panjang 33,25-38,12 $\mathrm{cm}$ sebanyak 9 ekor dengan persentase sebesar 21\%, ukuran dengan panjang 38,13-43,72 cm sebanyak 9 ekor dengan persentase sebesar $21 \%$, ukuran dengan panjang 43,73-50,13 cm sebanyak 15 ekor dengan persentase sebesar $36 \%$ dan ukuran dengan panjang 50,14-57,50 $\mathrm{cm}$ dengan sebanyak 7 ekor dengan persentase sebesar 17\% (Gambar 3).

Hasil tangkapan bubu pada ikan kerapu diketahui bobot terkecil sebesar 300 gram dan bobot terbesar pada berat 3.494 gram. Hasil penelitian didapatkan rentang berat antara 300-3.494 gram dilakukan pengolahan data dengan membagi rentang kelas menjadi 5 bagian yaitu rentang bobot kisaran 300-390,18 gram sebanyak 2 ekor dengan persentase sebesar 5\%, rentang bobot kisaran 390,19-800,93 gram sebanyak 11 ekor dengan persentase sebesar 28\%, rentang bobot kisaran 800,94$1.308,70$ gram sebanyak 12 ekor dengan persentase sebesar 29\%, rentang bobot kisaran 1.308,71-2.138,36 gram sebanyak 12 ekor dengan persentase sebesar 29\% dan rentang bobot kisaran 2.138,37-3.494 gram sebanyak 5 ekor dengan persentase sebesar

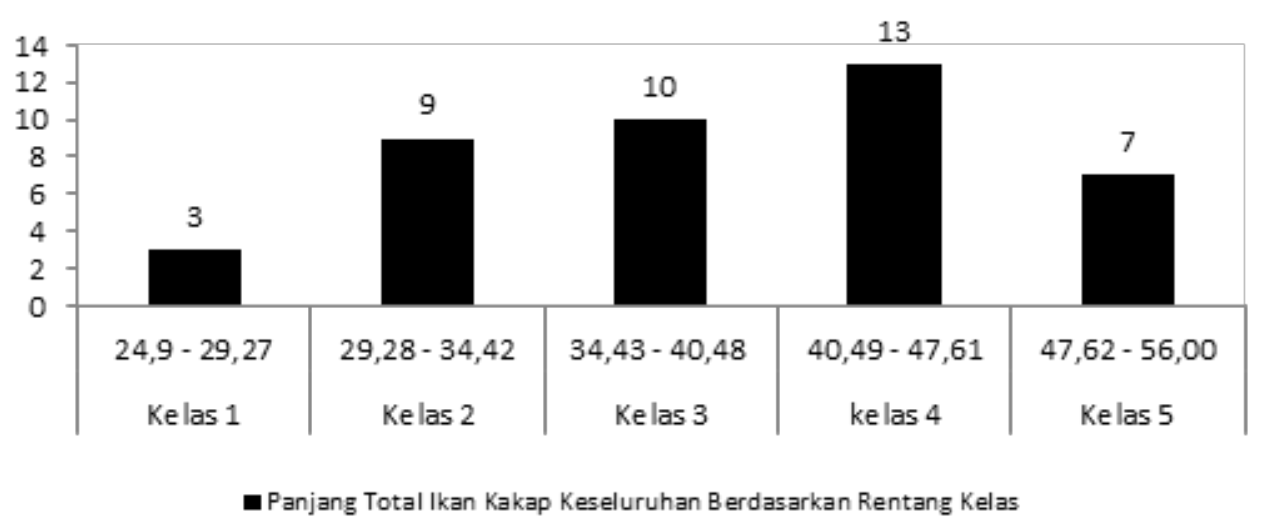

Gambar 1. Panjang total ikan kakap merah berdasarkan rentang kelas 


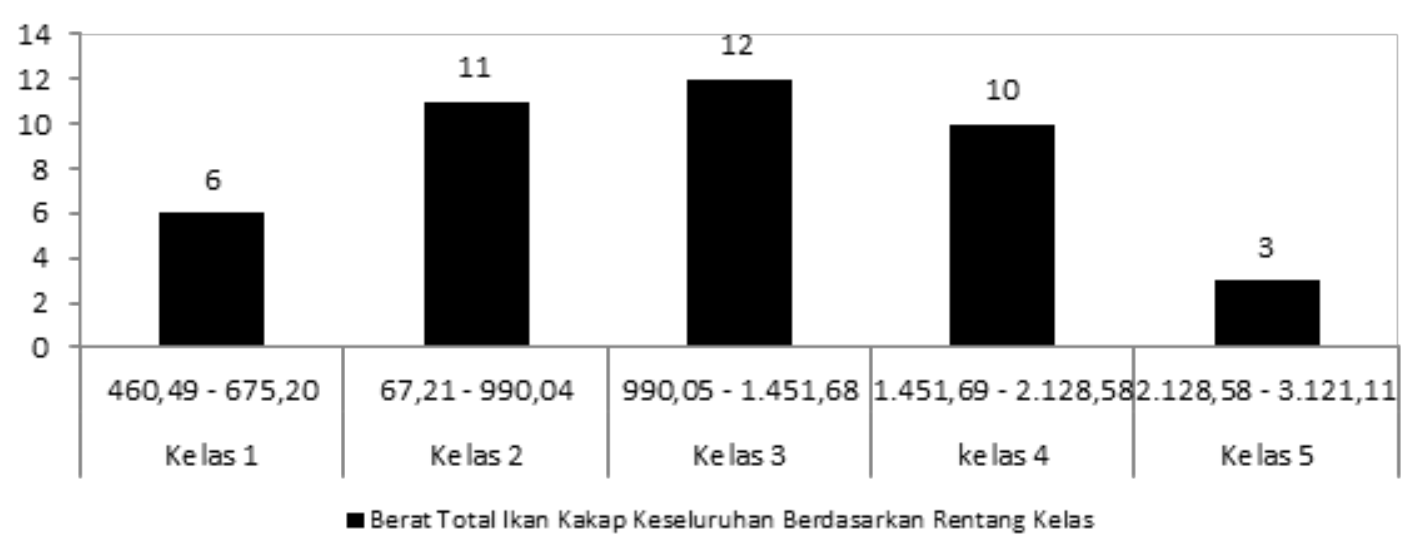

Gambar 2. Berat total ikan kakap merah berdasarkan rentang kelas

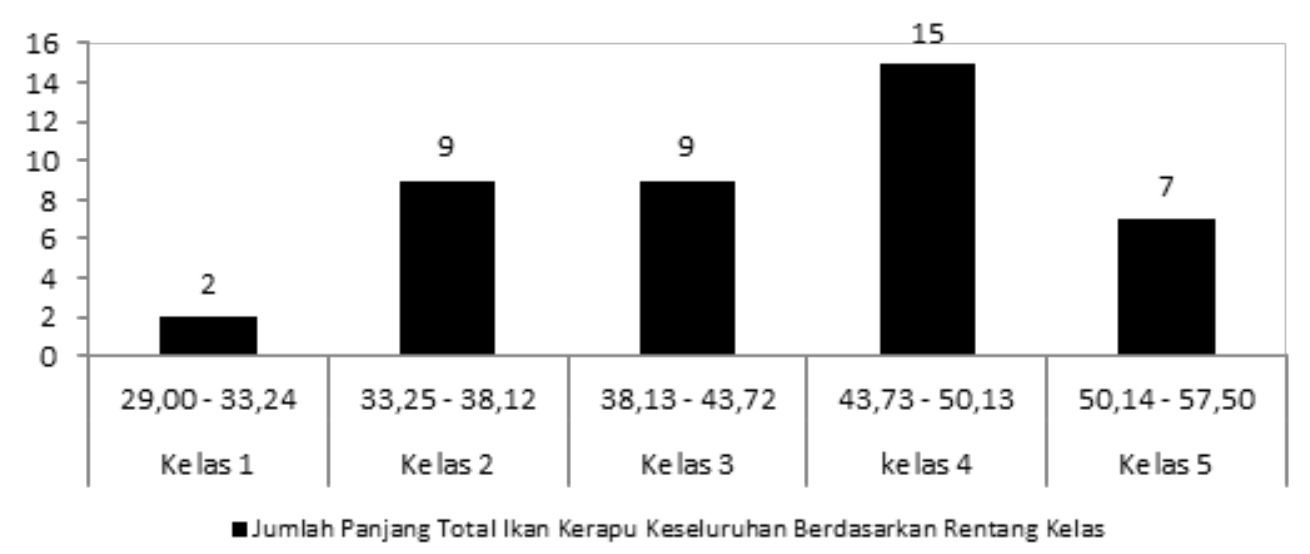

Gambar 3. Jumlah panjang total ikan kerapu berdasarkan rentang kelas

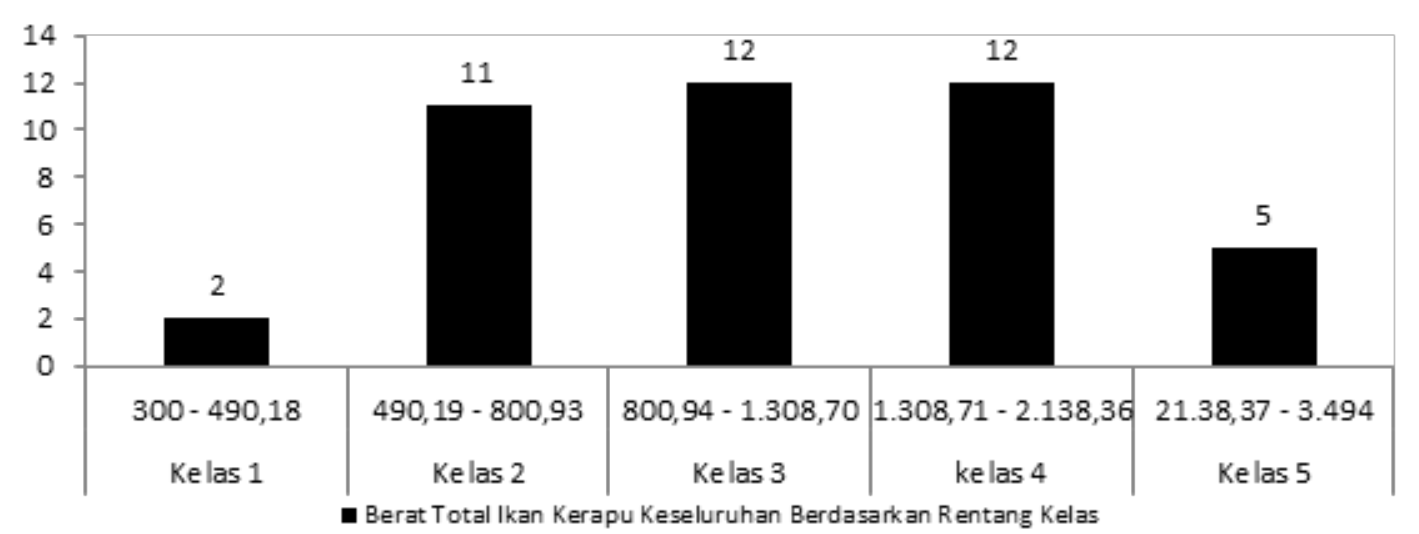

Gambar 4. Berat total ikan kerapu berdasarkan rentang kelas

$12 \%$ (Gambar 4).

Sifat pertumbuhan allometrik

Hasil penelitian mengenai ikan kakap yang didapatkan dari hasil tangkapan nelayan menggunakan alat tangkap bubu, didapatkan sebanyak 42 ekor jenis ikan kakap. Data penelitian tersebut dilakukan uji parameter pertumbuhan allometrik, dimana menggunakan tiga variable yaitu variable panjang total dan berat total, panjang standard dan berat total, panjang cagak dan berat total. Pada variabel hubungan antara panjang total dan berat total ikan kakap didapatkan nilai regresi logaritma linier yaitu nilai intercept (a) sebesar -0,999 dan nilai slope (b) sebesar 2,502, dengan nilai R2 sebesar 90,36\% dan korelasi (r) sebesar 95,06\% (Gambar 5). Pada hubungan ukuran panjang standar dan berat total diketahui nilai persamaan regresinya sebesar $-0,373$ (intersep/a), 2,238 (slope/b) dengan nilai R2 sebesar 86,22\% dan korelasi (r) sebesar $92,85 \%$ (Gambar 6). Hubungan ukuran panjang cagak dan berat total diketahui nilai persamaan regresinya sebesar $-0,826$ (intersep/a), 2,471 (slope/b) dengan nilai R2 sebesar 90,18\% dan korelasi (r) sebesar 


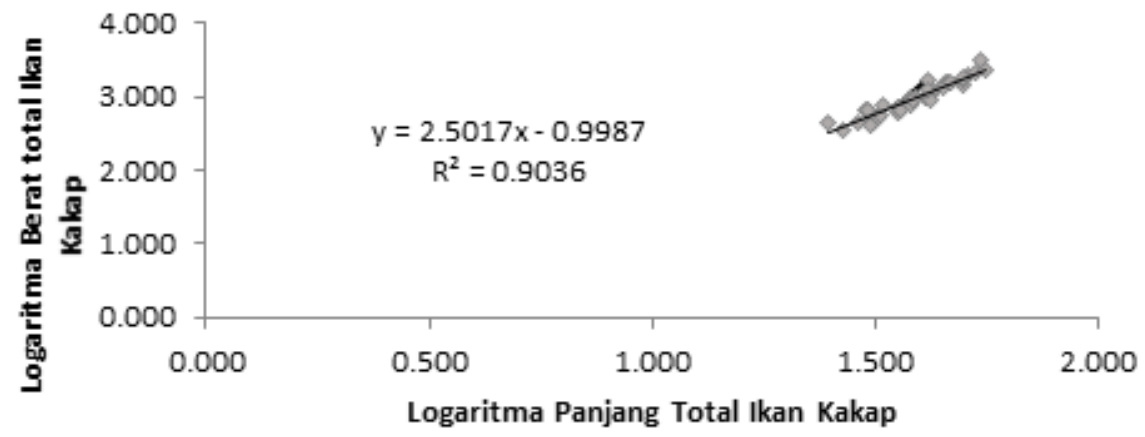

Gambar 5. Pertumbuhan panjang total dan berat total ikan kakap

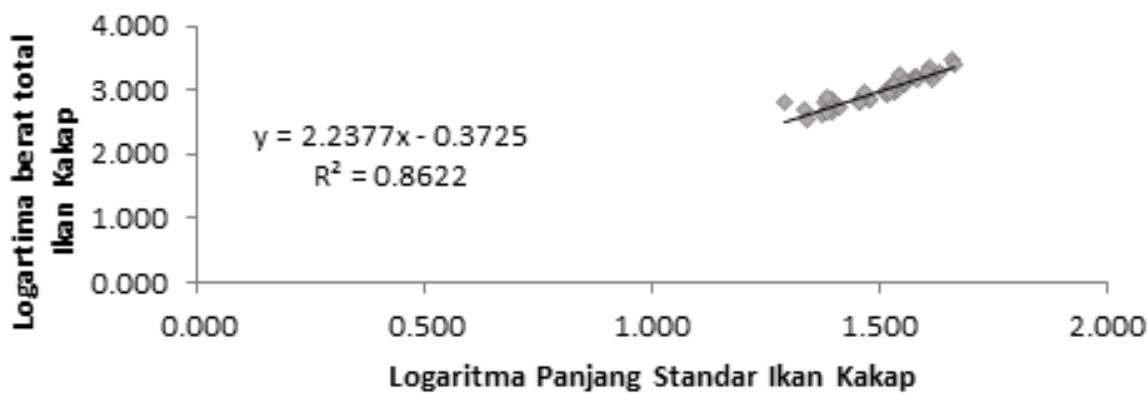

Gambar 6. Pertumbuhan panjang standar dan berat total ikan kakap

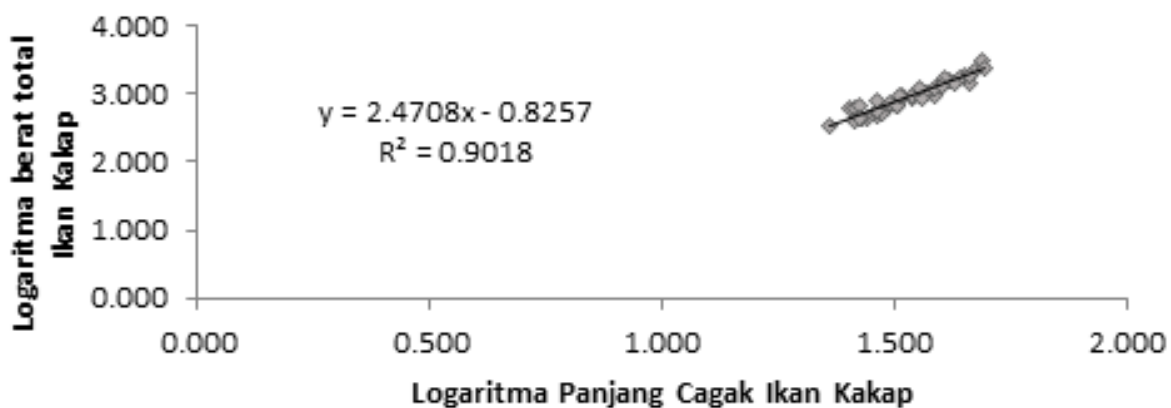

Gambar 7. Pertumbuhan panjang cagak dan berat total ikan kakap

94,96\% (Gambar 7).

Variabel hubungan panjang total dan berat total pada sampel ikan kerapu menghasilkan nilai persamaan regresi koefiesien intersep (a) sebesar -1.962, nilai koefisien slope (b) sebesar 3,069 dengan nilai R2 sebesar 88,49\% dan korelasi (r) sebesar 94,07\% (Gambar 8). Pada hubungan panjang standar dengan berat total didapat nilai regresi intersep (a) sebesar -1,316 dan nilai regresi slope (b) sebesar 2,856 dengan nilai R2 sebesar $86,79 \%$ dan korelasi (r) sebesar 93,16\% (Gambar 9). Hubungan ukuran panjang cagak dan berat total diketahui nilai persamaan regresinya sebesar $-1,330$ (intersep/a) dan 2,807 (slope/b) dengan nilai R2 sebesar $82,50 \%$ dan korelasi (r) sebesar 90,83 (Gambar 10).

Indeks kondisi

Indeks kondisi menurut Effendi (2002) menjelaskan mengenai bentuk tubuh suatu spesies. Sedangkan menurut Salim (2013) menjelaskan mengenai indeks kondisi yaitu angka yang menunjukkan suatu bentuk tubuh dari spesies ikan dimana dapat dilihat dari ukuran ataupun berat spesies ikan tertentu, untuk mendapatkan bentuk tubuh berdasarkan angka tersebut. Hasil analisa faktor kondisi pada sampel ikan kakap merah (L. argetimaculatus), bahwa pada variabel hubungan panjang total dan berat total diketahui nilai faktor kondisinya sebesar 
$50 \%$ bentuk tubuh kurus / pipih dan 40,48\% bentuk tubuh gemuk/montok (Gambar 11). Pada hubungan panjang standar dan berat total, nilai faktor kondisinya sebesar 52,38\% bentuk tubuh pipih/kurus dan 42,86\% bentuk tubuh gemuk/montok (Gambar 12). Hubungan faktor kondisi berdasarkan ukuran panjang cagak dan berat ikan kakap merah, diketahui bentuk tubuh pipih sebesar 57,14\% dan bentuk tubuh gemuk/ montok sebesar 40,48\% (Gambar 13).

Pada sampel ikan kerapu $(E$. malabaricus), berdasarkan variabel hubungan ukuran panjang total dan berat total, diketahui nilai faktor kondisi dengan persentase bentuk tubuh kurus/pipih sebesar 57,14\% dan bentuk tubuh montok/ gemuk sebesar 33,33\% (Gambar 14). Pada hubungan ukuran panjang standar dan berat total, diketahui berdasarkan nilai faktor kondisinya, bentuk tubuh pipih/ kurus sebesar 57,14\% dan bentuk tubuh gemuk/montok sebesar 35,17\% (Gambar 15). Pada ukuran panjang cagak dan berat total, diketahui bentuk tubuh pipih/kurus berdasarkan nilai faktor kondisinya sebesar 64,29\% dan bentuk tubuh gemuk/montok sebesar 30,95\% (Gambar 16).

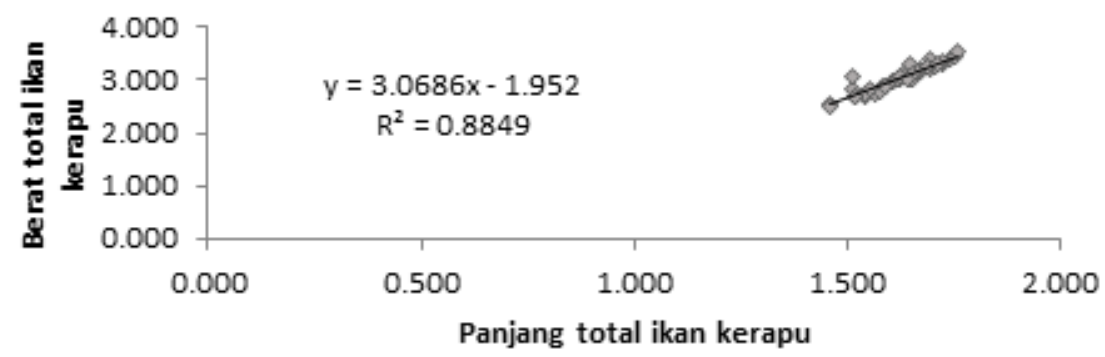

Gambar 8. Pertumbuhan panjang total dan berat total ikan kerapu

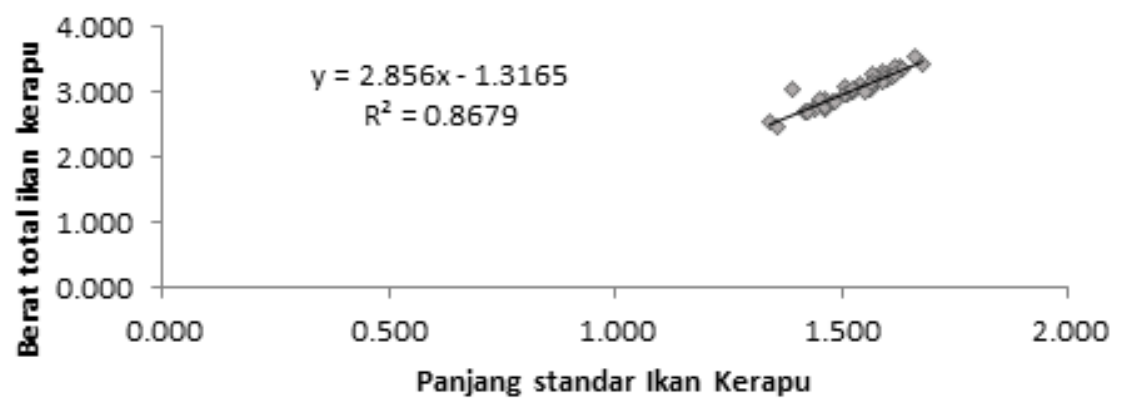

Gambar 9. Pertumbuhan panjang standar dan berat total ikan kerapu

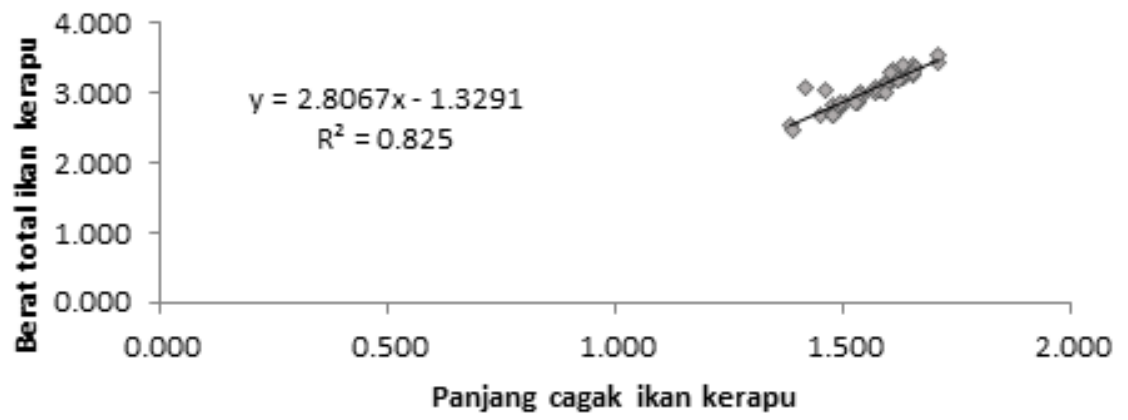

Gambar 10. Pertumbuhan panjang cagak dan berat total ikan kerapu 


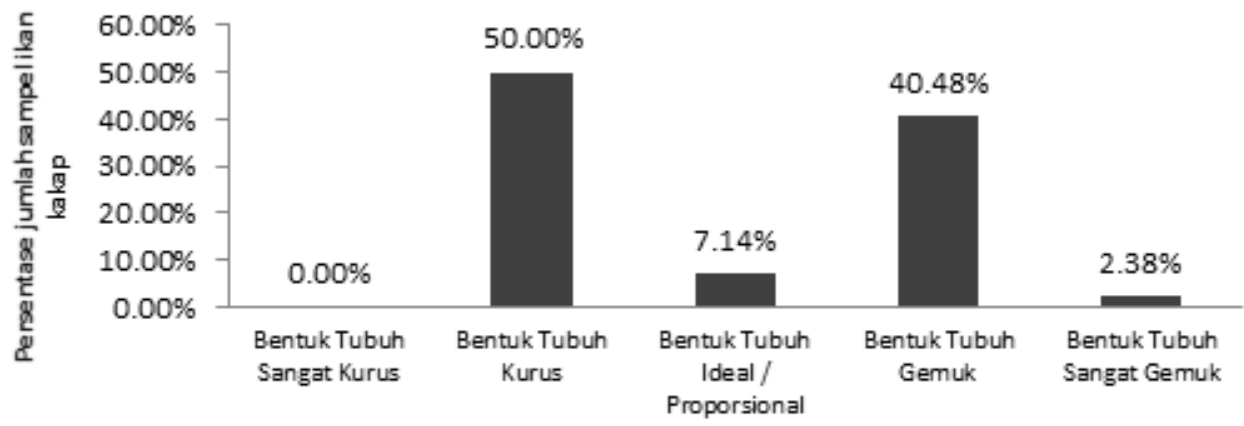

Indeks kondisi ikan kakap keseluruhan Panjang total dan Berat total

Gambar 11. Indeks kondisi panjang total dan berat total ikan kakap

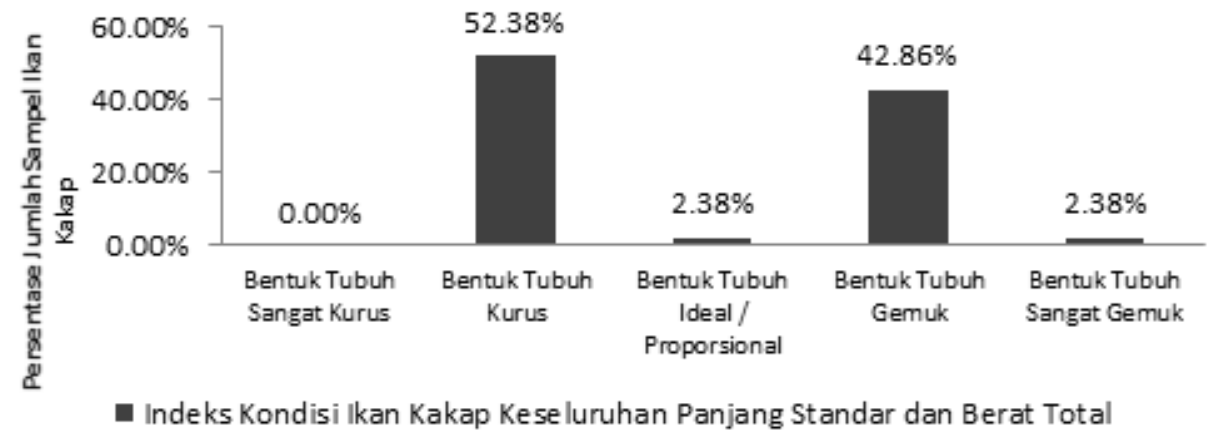

Gambar 12. Indeks kondisi panjang standar dan berat total ikan kakap

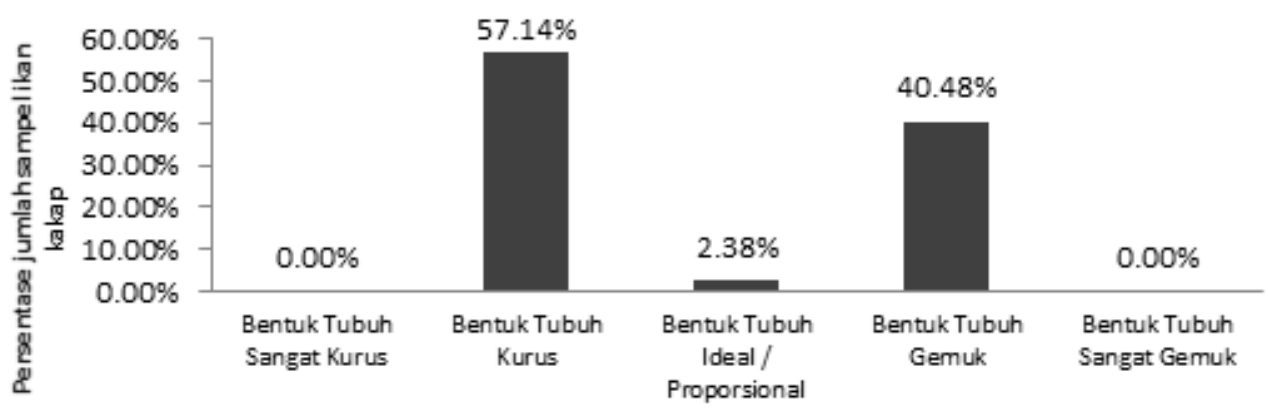

- Indeks Kondisi Ikan Kakap Keseluruhan Panjang Cagak dan Berat Total

Gambar 13. Indeks kondisi panjang cagak dan berat total ikan kakap

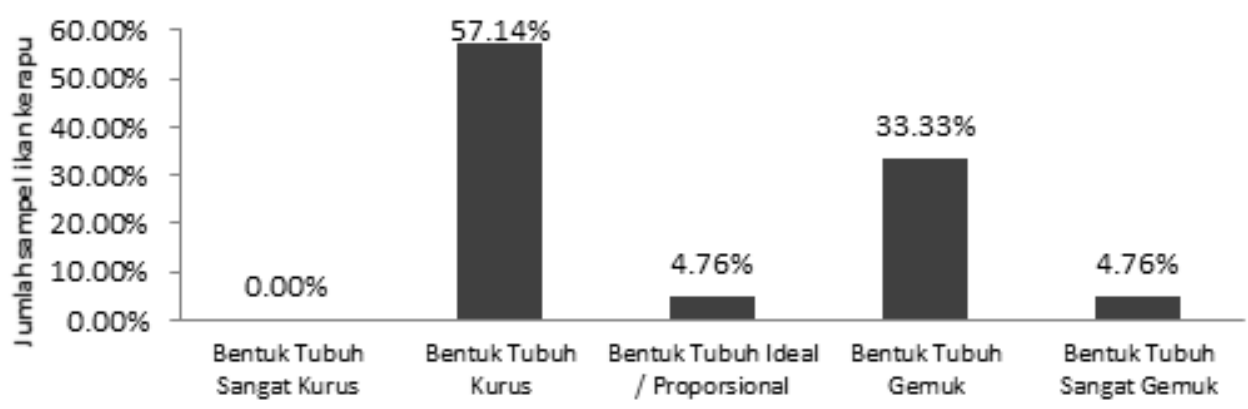

- Indeks Kondisi Ikan Kerapu Keseluruhan Panjang Total dan Berat Total

Gambar 14. Indeks kondisi panjang total dan berat total ikan kerapu 


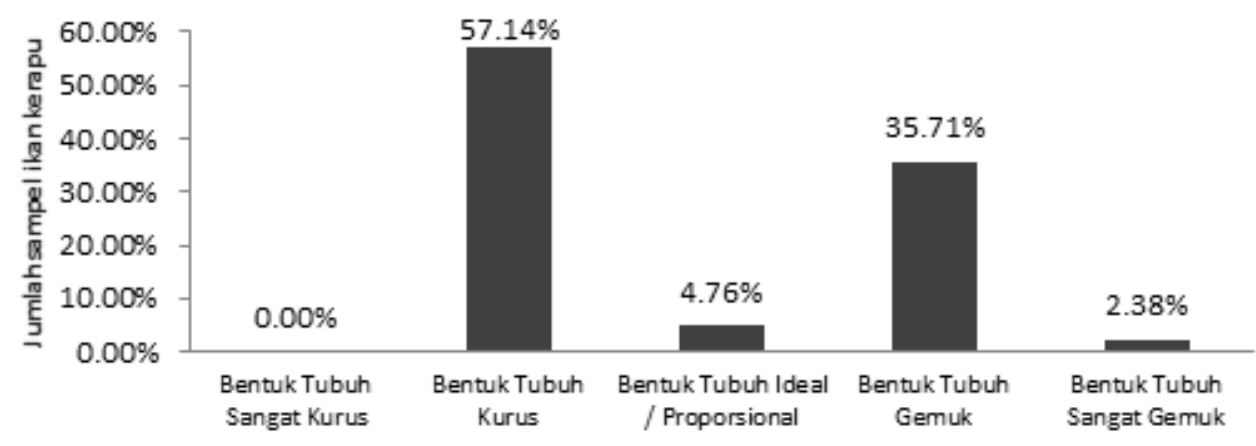

- Indeks Kondisi Ikan Kerapu Keseluruhan Panjang Standar dan Berat Total

Gambar 15. Indeks kondisi panjang standar dan berat total ikan kerapu

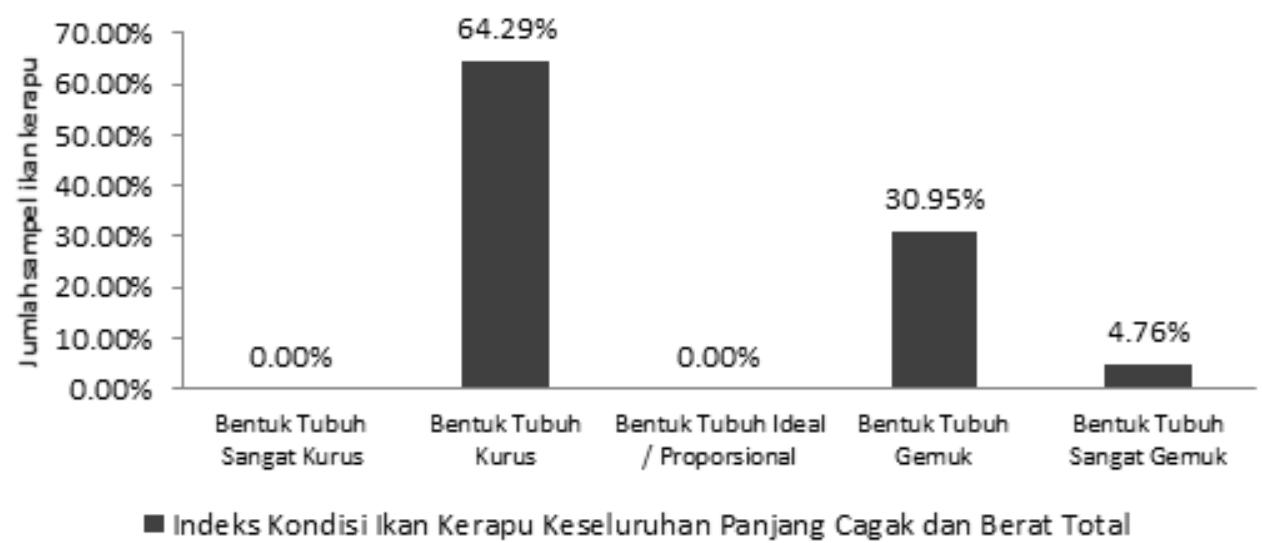

Gambar 16. Indeks kondisi panjang cagak dan berat total ikan kerapu

\section{Pembahasan}

Hubungan antara panjang total dan berat total pada sampel ikan kakap merah (L. argentimaculatus) didapat nilai b sebesar 2,502 ( $r=95,06 \%)$. Hubungan antara panjang standar dengan berat total didapatkan nilai b sebesar 2,238 ( $\mathrm{r}=92,85 \%)$ dan pada hubungan antara panjang cagak dan berat total didapatkan nilai 2,471 $(\mathrm{r}=$ $94,96 \%)$. Hasil penelitian dari ketiga variabel hubungan ukuran panjang-berat tersebut diketahui bahwa nilai b kurang dari $3(\mathrm{~b}<3)$. Nilai $b$ ini menggambarkan mengenai hasil pertumbuhan ikan kakap merah di perairan pulau Bunyu kategori pertumbuhannya bersifat allometrik negatif. Hasil berbeda pada sampel ikan kakap dengan nilai $b$ > 3 (allometrik positif) di perairan Bunaken Sulawesi Selatan (Holloway et al. 2015). Makna nilai b yang kurang dari 3 bahwa pertumbuhan antara ukuran panjang dan berat dari ikan kakap merah di perairan Bunyu tidak seimbang, dengan ketentuan bahwa pertumbuhan ukuran panjang lebih cepat dibandingan dengan pertumbuhan berat ikan. Menurut Effendi
(2002) menjelaskan mengenai apabila nilai b kurang dari 3 maka pertumbuhan bersifat allometrik negatif dengan penjelasan pertumbuhan panjang total dari ikan lebih cepat dibandingkan dengan pertumbuhan berat total ikan. Hal ini dibuktikan dengan tingkat nilai korelasi yang rerata lebih besar dari 90\% yang menjelaskan bahwa antar hubungan ukuran panjang dan berat memiliki hubungan yang sangat kuat. Menurut Sarwono (2006) menjelaskan mengenai nilai tingkat korelasi kisaran antara 80\%-99\% menjelaskan korelasi memiliki hubungan yang sangat kuat. Berarti sangat kuat dugaan pertumbuhan ikan kakap merah memiliki pertumbuhan yang bersifat allometrik negatif dimana semakin bertambah pertumbuhan panjang ikan akan diikuti dengan pertumbuhan berat ikan, namun demikian pertumbuhan panjang ikan lebih cepat dibandingkan dengan pertumbuhan berat ikan kakap merah di perairan pulau Bunyu. Perairan selatan Banten, diketahui hubungan panjang berat dari sampel ikan kakap dengan nilai $b=3$ (isometrik) pada sampel jantan dan betina family Lutjanidae (Prihatiningsih et al. 2017). Hasil penelitian yang sama dengan 
penelitian ini adalah dari sampel ikan kakap merah di perairan Labuan Pendegang Banten, diketahui nilai $\mathrm{b}<3$ (allometrik negatif) yang bermakna, pertumbuhan panjang lebih cepat dibandingkan dengan pertambahan berat (Imbalan 2013).

Hubungan antara panjang total dan berat total pada sampel ikan kerapu ( $E$. malabaricus) didapat nilai b sebesar 3,069 $(\mathrm{r}=94,07 \%)$. Hubungan antara panjang standar dengan berat total didapatkan nilai $\mathrm{b}$ sebesar 2,856 $(\mathrm{r}=93,16 \%)$ dan pada hubungan antara panjang cagak dan berat total didapatkan nilai 2,8067 $(r=90,83 \%)$. Hasil penelitian dari ketiga variabel hubungan ukuran panjang-berat tersebut diketahui hasil yang berbeda dimana untuk hubungan panjang total dan berat total didapatkan nilai $\mathrm{b}>3$ sedangkan untuk dua variable yaitu hubungan antara panjang standar dan berat total serta hubungan antara panjang cagak dan berat total didapatkan nilai $\mathrm{b}$ kurang dari $3 \mathrm{~b}<$ 3). Nilai $b$ pada hubungan ukuran panjang dan berat secara umum bersifat allometrik positif yaitu nilai $b$ yang lebih besar dari 3. Adapun nilai $\mathrm{b}$ pada hubungan panjang standar dan panjang cagak terhadap ukuran berat, secara riil nilai ukuran tubuh berbentuk gemuk/montok dan secara kuantitatif regresi mendekati nilai 3 yang berarti lebih ke arah allometrik positif, walaupun secara nilai riil regresi (b) bermakna allometrik negatif. Sampel ikan kerapu family Serranidae di perairan Pulo Aceh Kabupaten Aceh Besar, diketahui bahwa jenis $E$. fuscoguttatus memiliki nilai b $=2,85$ dan jenis $E$. bleekeri dengan nilai $\mathrm{b}=$ 2,84 , yang bermakna pola pertumbuhannya allometrik negatif (Ramadhani et al. 2017).

$$
\text { Namun demikian untuk }
$$

menggambarkan secara keseluruhan menggunakan pertumbuhan antara panjang total dan berat total dimana panjang total digunakan untuk mengukur secara keseluruhan dari berat total yang didapatkan. Hasil antara hubungan panjang total dan berat total didapatkan allometrik positif dikarenakan nilai yang didapat dari persamaan regresi berdasarkan nilai b nya adalah lebih dari angka 3. Makna nilai yang b yang lebih dari 3 bahwa pertumbuhan ukuran panjang dan berat tidak seimbang, yang dalam hal ini pertumbuhan ukuran berat ikan kerapu lebih cepat dibandingan dengan pertumbuhan ukuran panjangnya. Menurut Effendi (2002) menjelaskan mengenai apabila nilai b lebih dari 3 maka pertumbuhan bersifat allometrik positif dengan penjelasan pertumbuhan berat total lebih cepat dibandingkan dengan pertumbuhan panjang total ikan. Hal ini dibuktikan dengan tingkat nilai korelasi yang rerata lebih besar dari $80 \%$ yang bermakna memiliki hubungan sangat kuat antara ukuran panjang dan berat. Menurut Sarwono (2006) menjelaskan mengenai nilai tingkat korelasi kisaran antara 80\%-99\% menjelaskan korelasi memiliki hubungan yang sangat kuat. Berarti sangat kuat dugaan pertumbuhan ikan kerapu memiliki pertumbuhan yang bersifat allometrik positif dimana semakin bertambah pertumbuhan berat ikan akan diikuti dengan pertumbuhan panjang ikan, namun demikian pertumbuhan berat ikan lebih cepat dibandingkan dengan pertumbuhan panjang ikan kerapu di perairan pulau Bunyu. Hasil yang berbeda diketahui dari sampel ikan kerapu (Epinepheus sp.) di perairan Taman Nasional Wakatobi, bahwa pola pertumbuhan ikan kerapu yang tertangkap dengan pancing dan bubu menunjukkan pola pertumbuhan allometrik negatif (Tadjuddah et al. 2013). Demikian halnya pada sampel ikan kerapu (P. leopardus) di perairan Kepulauan Spermonde Sulawesi Selatan, dengan nilai pola pertumbuhan allometrik negatif (Ernaningsih et al. 2015).

Hal ini menjelaskan perbedaan pertumbuhan allometrik antara ikan kakap dan ikan kerapu dimana pertumbuhan ikan kakap dan ikan kerapu memiliki perbedaan. Pertumbuhan ikan kakap merah didapatkan pertumbuhan allometrik negatif dan pertumbuhan ikan kerapu didapatkan pertumbuhan allometrik positif. Hal ini menunjukkan bahwa pertumbuhan ikan kakap dan ikan kerapu diduga memiliki kesamaan dikarenakan menjadikan daerah perairan pulau Bunyu sebagai salah satu area tempat makan bagi kelangsungan hidup serta ikan kakap merah bersifat allometrik negatif diduga ikan ini mencari makanan bersaing dengan kerapu. Ikan kakap diduga tidak memiliki kemampuan dan kecepatan dari ikan kerapu sehingga dalam persaingan mencari makanan, ikan kakap tidak dapat berkompetisi mencari makanan dengan ikan kerapu. Hal ini dibuktikan dengan dua kondisi tubuh ikan yang didapatkan berbeda jauh. Dimana kondisi tubuh ikan kerapu lebih panjang $57,5 \mathrm{~cm}$ dibandingkan dengan ikan kakap sebesar $56 \mathrm{~cm}$ dan dilihat dari kondisi bobot tubuh bahwa ikan kerapu lebih besar didapatkan sebesar 3.494 gram dibandingkan dengan ikan kakap merah 
sebesar 3.121,11 gram.

Perbedaan nilai b dalam menggambarkan pola pertumbuhan ikan kakap bermakna adanya perbedaan dalam faktor lingkungan dan fisiologis ikan kakap tersebut dalam pola makan dan makanan. Analisa hubungan panjang-berat bertujuan untuk mengetahui pola pertumbuhan biota perairan (Ridho dan Patriono 2016). Hubungan tersebut menerangkan pertumbuhan, kemontokan, dan perubahan lingkungan. Arah pertumbuhan pada nilai negatif dan positif menandakan bentuk tubuh pada bentuk pipih/kurus (negatif) dan gemuk/montok (positif). Bentuk tubuh pada pola pertumbuhan tersebut dipengaruhi oleh lingkungan perairan dan makanan. Dijelaskan oleh Firdaus et al. (2018) bahwa nilai hubungan panjang berat biota perairan yang menggambarkan sifat pertumbuhannya tidak konstan/tidak selalu sama. Hal ini karena ragam faktor, antara lain perubahan lingkungan dan faktor ketersediaan makanan. Ditambahkan oleh Muchlisin et al. (2015) menjelaskan bahwa nilai b diasumsikan banyak dipengaruhi oleh ketersediaan makanan dan kondisi lingkungan seperti suhu, $\mathrm{pH}$, dan oksigen terlarut.

Hasil pengolahan data secara keseluruhan berdasarkan panjang total dan berat total didapat bentuk tubuh dominan pada sampel ikan kakap merah adalah bentuk tubuh kurus sebesar 50\%, bentuk tubuh gemuk sebesar 40,48\% (Gambar 11). Pada sampel ikan kerapu, bentuk tubuh kurus/pipih sebesar 57,14\% dan bentuk tubuh gemuk/montok sebesar 33,33\% (Gambar 14). Hasil bentuk tubuh ikan kakap berdasarkan panjang total paling dominan memiliki bentuk tubuh kurus, hal ini sesuai dengan sifat pertumbuhan dari ikan kakap berdasarkan panjang total dan berat total bersifat allometrik negatif. Makna nilai tersebut adalah pertumbuhan panjang lebih cepat daripada pertumbuhan beratnya. Hal ini diduga bahwa pertumbuhan ikan kakap merah dalam mencari makanan bersifat kelompok dan ikan ini memiliki tingkat agresifitas yang cukup tinggi serta sebagai perenang cepat yang digunakan untuk menjauhi predator dan mencari makan, sehingga energi yang terdapat dalam tubuh ikan kakap ini banyak terkuras untuk kegiatan berenang dengan pertumbuhan panjang lebih cepat daripada beratnya sehingga menyebabkan bobot tubuh ikan kakap berbentuk kurus.

Indeks kondisi ikan kakap merah berdasarkan antara panjang standar dan panjang cagak dengan berat total, didapatkan bentuk dominan yang sama, dimana bentuk tubuh dominan yaitu bentuk tubuh kurus/pipih berdasarkan panjang standar sebesar 52,38\% dan bentuk dominan berdasarakan panjang cagak dengan berat total didapatkan bentuk tubuh kurus sebesar 57,14\% (Gambar 12 dan 13). Hasil dua variabel yaitu panjang standar dan panjang cagak yang berkorelasi dengan berat tubuh ikan kakap berbentuk kurus/ pipih, sesuai dengan sifat pertumbuhannya yaitu allometrik negatif. Hal ini menjelaskan bahwa ikan kakap beradaptasi terhadap lingkungan dalam mencari makanan ataupun dalam menghindari predator cukup gesit dan diduga ikan kakap kalah bersaing dalam makanan dengan ikan kerapu yang menyebabkan ikan kakap menghidari sesama pemakan karnivora salah satunya ikan kerapu. Dijelaskan oleh Bagarinao (1995) dalam Melianawati dan Andamari (2009) bahwa dengan bentuk tubuh yang kurus / pipih (allometrik negatif) dan sifatnya sebagai predator yang aktif maka faktor kondisinya cenderung berada pada kisaran yang lebih kecil.

Berdasarkan hasil penelitian antara panjang standar dan berat total hanya terdapat empat kriteria bentuk tubuh yang didapatkan yaitu bentuk tubuh kurus, bentuk tubuh ideal, bentuk tubuh gemuk, dan bentuk tubuh sangat gemuk. Bentuk tubuh dominan didapatkan bentuk tubuh kurus dan bentuk tubuh yang sedikit yaitu bentuk tubuh ideal $(2,38 \%)$ dan bentuk tubuh sangat gemuk (2,38\%). Hal ini berbeda dengan hasil penelitian dari variabel panjang cagak dengan berat total dimana didapatkan tiga kriteria bentuk tubuh yaitu bentuk tubuh kurus, bentuk tubuh ideal/proporsional dan bentuk tubuh gemuk. Bentuk tubuh dominan didapatkan bentuk tubuh kurus dan bentuk tubuh yang ditemukan jumlahnya sedikit terdapat pada bentuk tubuh ideal (2,38\%).

Hasil penelitian ikan kerapu yang dilakukan pengolahan data ikan kakap secara keseluruhan berdasarkan panjang total dan berat total didapatkan bentuk tubuh dominan dari ikan kerapu adalah bentuk tubuh kurus sebesar 57,14\%, bentuk tubuh gemuk sebesar 33,33\%, bentuk tubuh ideal atau proporsional dan bentuk tubuh sangat gemuk, memiliki persentase yang sama sebesar 4,76\% (Gambar 14). Hasil pengolahan data dalam variabel bentuk tubuh ikan kerapu berdasarkan 
panjang total paling dominan memiliki bentuk tubuh kurus, hal ini tidak sesuai dengan gambaran sifat pertumbuhan secara keseluruhan dari penelitian ikan kerapu berdasarkan panjang total dan berat total dengan memiliki sifat allometrik positif atau pertumbuhan berat lebih cepat daripada pertumbuhan panjangnya. Hal ini diduga bahwa pertumbuhan ikan kerapu secara keseluruhan energi yang didapatkan lebih dominan ke arah bentuk tubuh dan diduga dalam kompetisi persaingan makanan, ikan kerapu lebih agresif dibandingkan ikan sejenis pemakan karnivora sehingga secara keseluruhan ikan kerapu berbentuk gemuk sedangkan bentuk tubuh per-individu ditemukan paling banyak dominan adalah memiliki bentuk tubuh kurus, diduga dalam mencari makanan bersifat kelompok dan ikan ini memiliki tingkat agresifitas yang tinggi dan sebagai perenang cepat dalam mendapatkan makanan sealain itu energi yang terdapat dalam tubuh ikan kakap ini banyak terkuras untuk kegiatan berenang dengan cara migrasi untuk mendapatkan makanan sehingga menyebabkan bobot tiaptiap individu tubuh ikan kerapu berbentuk kurus.

Indeks kondisi ikan kerapu berdasarkan variabel antara panjang standar dan panjang cagak yang dikorelasikan dengan berat total, didapatkan bentuk tubuh yang dominan sama, dimana bentuk tubuh dominan yang ditemukan berupa bentuk tubuh kurus. Bentuk tubuh kurus berdasarkan variabel panjang standar dengan berat total didapatkan sebesar $57,14 \%$ dan bentuk dominan berdasarakan variabel panjang cagak korelasi berat total dengan bentuk tubuh kurus sebesar $64,29 \%$ (Gambar 15 dan 16). Hasil penelitian dari dua variabel yaitu panjang standar dan panjang cagak yang berkorelasi dengan berat tubuh ikan kerapu berbentuk kurus, hal ini sesuai dengan sifat pertumbuhan secara keseluruhan (populasi) yaitu bersifat allometrik negatif. Hal ini menjelaskan bahwa ikan kerapu dalam beradaptasi terhadap lingkungan untuk berkompetisi dalam mencari makanan ataupun dalam menghindari predator di alam dan diduga ikan kerapu memiliki alur migrasi yang luas dalam mencari makanan sehingga menyebabkan ikan kerapu memiliki bentuk tubuh kurus. Berdasarkan hasil penelitian ikan kerapu menggunakan variabel antara panjang standar dan berat total hanya terdapat empat kriteria bentuk tubuh yang didapatkan yaitu bentuk tubuh kurus, bentuk tubuh ideal, bentuk tubuh gemuk, dan bentuk tubuh sangat gemuk. Bentuk tubuh dominan didapatkan bentuk tubuh kurus sebesar $57,14 \%$ dan bentuk tubuh yang ditemukan sedikit yaitu bentuk tubuh ideal sebesar 2,38\% (Gambar 15). Hal ini berbeda dengan hasil penelitian ikan kerapu menggunakan variabel panjang cagak dengan berat total (Gambar 16) dimana didapatkan tiga kriteria bentuk tubuh yaitu bentuk tubuh kurus $(64,29 \%)$, bentuk tubuh gemuk $(30,95 \%)$, dan bentuk tubuh sangat gemuk (4,76\%). Bentuk tubuh dominan didapatkan bentuk tubuh kurus sebesar 64,29\% dan bentuk tubuh yang ditemukan jumlahnya sedikit terdapat pada bentuk tubuh sangat gemuk sebesar $4,76 \%$ (Gambar 16).

Berdasarkan hasil riset terkait dengan kondisi tubuh ikan kakap dan ikan kerapu yang tertangkap pada bubu dasar di perairan Bunyu, secara umum berbentuk tubuh kurus berdasarkan variabel panjang (total, standar, dan cagak) dan berat. Terdapat bentuk tubuh kurus $50 \%$ pada sampel ikan kakap pada variabel ukuran panjang total dan berat. Pada variabel ukuran panjang standar dan berat, terdapat $52,38 \%$ bentuk tubuh kurus dan $57,14 \%$ berbentuk tubuh kurus berdasarkan variabel panjang cagak dan berat pada sampel ikan kakap merah. Pada sampel ikan kerapu lumpur, terdapat $57,14 \%$ berdasarkan variabel panjang totalberat dan variabel panjang standar-berat. Pada variabel panjang cagak-berat, terdapat 64,29\% sampel ikan kerapu berbentuk tubuh kurus. Nilai indeks pertumbuhan yang menggambarkan kondisi bentuk tubuh ikan pada perikanan bubu dasar di perairan Bunyu, idealnya dapat dipergunakan sebagai informasi dasar secara ilmiah dalam penentuan selektivitas alat tangkap atau pengaturan penangkapan yang terkait dengan pola pengelolaan sumberdaya ikan. Dijelaskan oleh Mulfizar (2012) bahwa analisa indeks pertumbuhan bermanfaat pada penentuan selektivitas dalam pengelolaan perikanan tangkap. Solusi yang diajukan peneliti dalam pengelolaan sumberdaya ikan pada perikanan bubu dasar di perairan Bunyu berdasarkan hasil penelitian yaitu adanya pengendalian waktu penangkapan (fishing time/fishing season), area penangkapan (fishing area) dan pengaturan teknis alat tangkap bubunya. Nilai parameter pertumbuhan ikan, termasuk di dalamnya adalah bentuk/ kondisi tubuh ikan, digunakan sebagai dasar kebijakan pengelolaan sumberdaya 
ikan dalam penangkapan/pemanfaatanya. Parameter pertumbuhan jenis ikan kakap merah dan ikan kerapu lumpur, telah banyak diteliti di berbagai perairan Indonesia dan nilai-nilai parameter tersebut dapat dipergunakan sebagai dasar ilmiah dalam pengelolaan pemanfaatan sumberdaya ikan (Melianawati dan Andamari 2009; Sumiono et al. 2010; Wahyuningsih et al. 2013; dan Prihatiningsih et al. 2017). Informasi kondisi tubuh ikan dari hasil penelitian ini yang terkategori umumnya adalah kurus, menjadi dasar yaitu dengan sistem pengaturan jarak durasi waktu pada tahapan setting-hauling antar bubu. Pada kondisi riil di perairan Bunyu, rerata setiap nelayan memiliki 30 bubu dan diletakkan pada perairan Bunyu secara acak sesuai pengalaman penangkapan dan pengoperasian bubunya dengan sistem set-haul setiap hari. Tidak adanya pengaturan terkait dengan jumlah bubu per nelayan, pengaturan sebaran bubu secara parsial (wilayah) dan temporal (waktu penangkapan) serta pengaturan pola setting-hauling.

\section{KESIMPULAN DAN SARAN}

\section{Kesimpulan}

Sampel ikan kakap yang tertangkap di perairan Bunyu memiliki ukuran panjang 40,49-47,61 cm sebanyak 13 ekor dan rentang bobot 990,05-1.451,68 gram sebanyak 12 ekor. Ikan kerapu memiliki ukuran panjang 43,73-50,13 $\mathrm{cm}$ sebanyak 15 ekor serta rentang bobot 800,94-1.308,70 gram dan rentang bobot kisaran 1.308,71$2.138,36$ gram masing-masing sebanyak 12 ekor. Sifat pertumbuhan baik panjang total, panjang standar, dan panjang cagak dengan berat total, memiliki sifat allometrik negatif dengan indeks kondisi berbentuk kurus pada sampel ikan kakap merah. Ikan kerapu, sifat pertumbuhan panjang total dengan berat total bersifat allometrik positif namun berbeda dengan sifat pertumbuhan antara panjang cagak, panjang standar dengan berat total bersifat allometrik negatif dengan nilai indeks kondisi berbentuk kurus. Nilai pertumbuhan (bentuk/kondisi tubuh ikan) pada sampel ikan kakap dan ikan kerapu, mengindikasikan adanya penurunan size (ukuran) ikan hasil tangkapan bubu dasar.

\section{Saran}

Agar pengelolaan sumberdaya ikan kakap dan ikan kerapu di perairan Bunyu Kalimantan Utara mampu memberi nilai kesejahteraan masyarakat serta kelestarian biota dan lingkungannya, maka sangat penting memperhatikan dan menjadikan informasi penelitian ini sebagai dasar ilmiah dalam pengelolaan perikanan bubu dasar, baik kebijakan pengendalian waktu dan area penangkapan serta pengaturan teknis unit penangkapannya, agar indikasi penurunan size (ukuran) ikan hasil tangkapan bubu dasar dapat dikendalikan dan diatur.

\section{UCAPAN TERIMA KASIH}

Ucapan terimakasih diberikan kepada Kementerian Riset dan Teknologi Pendidikan Tinggi Republik Indonesia (KEMRISTEK DIKTI RI) dan Lembaga Penelitian dan Pengabdian kepada Masyarakat (LPPM) Universitas Borneo Tarakan yang telah mendukung pendanaan Penelitian dalam Hibah Riset Dasar Tahun 2019.

\section{DAFTAR PUSTAKA}

Effendie MI. 2002. Biologi Perikanan. Yogyakarta: Institut Pustaka Nusantara.

Ernaningsih, Budimawan, Nessa N, Sudirman. 2015. Keragaman Biologis Ikan Kerapu Sunu (Plectropomus leopardus) di Kepulauan Spermonde Sulawesi Selatan. Torani: Journal of Fisheries and Marine Science. 25(3): 157-163.

Firdaus M, Lelono TD, Saleh R, Bintoro G, Salim G. 2018. The Expression of The Body Shape in Fish Spesies Harpadon nehereus (Hamilton, 1822) in the Waters of Juata Laut Tarakan City, North Kalimantan. Jurnal Aquaculture, Aquarium, Conservation \& Legislation (AACL). 11(3): 613-624.

Hatapayo R. 2004. Pengaruh Penggunaan Umpan yang Berbeda pada Bubu Dasar di Perairan Tehoru Kabupaten Maluku Tengah [Skripsi]. Makassar: Universitas Muslim Indonesia. 
Holloway CJ, Bucher DJ, Kearney L. 2015. A Preliminary Study of the Age and Growth of Paddletail Snapper Lutjanus gibbus (Forsskål 1775) in Bunaken Marine Park, North Sulawesi, Indonesia. Asian Fisheries Science. 28(4): 186-197.

Imbalan A. 2013. Telaah Aspek Biologi dan Aspek Perikanan Ikan Kakap Merah Lutjanus gibbus (Forsskål 1775) dan Lutjanus erythropterus (Bloch 1790) yang Didaratkan di Pelabuhan Perikanan Pantai (PPP) Labuan Pandeglang Banten [Tesis]. Depok: Universitas Indonesia.

Jennings S, Kaiser MJ, Reynolds JD. 2001. Marine Fisheries Ecology. Blackwell, Malden.

Melianawati R, Andamari R. 2009. Hubungan Panjang-Bobot, Pertumbuhan, dan Faktor Kondisi Ikan Kakap Merah, Lutjanus argentimaculatus dari Hasil Budidaya. J. Ris. Akuakultur. 4(2): 169-178.

Muchlisin ZA, Batubara AS, Siti-Azizah MN, Adlim M, Hendri A, Fadli N, Muhammadar AA, Sugianto S. 2015. Feeding Habit and Length Weight Relationship of Keureling Fish, Tor tambra Valenciennes, 1842 (Cyprinidae) from The Western Region Aceh Province, Indonesia. Biodiversitas. 16(1): 89-94.

Mulfizar, Zainal A, Muchlisin ZA, Dewiyanti I. 2012. Hubungan Panjang Berat dan Faktor Kondisi Tiga Jenis Ikan yang Tertangkap di Perairan Kuala Gigieng Aceh Besar Propinsi Aceh. Jurnal DEPIK. 1(1): 1- 9.

Nuraini S. 2007. Jenis Ikan Kerapu (Serranidae) dan Hubungan Panjang Bobot di Perairan Berau, Kalimantan Timur. Jurnal Iktiologi Indonesia. 7(2): 61-65.

Prihatiningsih, Kamal MM, Kurnia R, Suman A. 2017. Hubungan Panjang Berat Kebiasan Makanan dan Reproduksi Ikan Kakap Merah (Lutjanus gibbus: Famili Lutjanidae) di Perairan Selatan Banten. Jurnal Bawal. 9(1): 21-32.
Raeisi H, Daliri M, Paighambari SY, Shabani MJ, Bibak M, Davoodi R. 2011. Length-Weight Relationships, Condition Factors, and Relative Weight of Five Fish Species of Bushehr Waters, Northern Persian Gulf. African Journal of Biotechnology. 10(82): 19181-19186.

Ramadhani A, Muchlisin ZA, Sarong MA, Batubara AS. 2017. Hubungan Panjang Berat dan Faktor Kondisi Ikan Kerapu Famili Serranidae yang Tertangkap di Perairan Pulo Aceh Kabupaten Aceh Besar, Provinsi Aceh. Depik Jurnal Ilmu-Ilmu Perairan, Pesisir, dan Perikanan. 6(2): 112-121.

Ridho MR, Patriono E. 2016. Aspek Reproduksi Ikan Kakap Putih (Lates calcarifer Block) di Perairan Terusan dalam Kawasan Taman Nasional Sembilang Pesisir Kabupaten Banyuasin. Jurnal Penelitian Sains. 18(1): 1-7.

Salim G. 2013. Nilai Indeks Kondisi dari Ikan Siganus javus berdasarkan Hasil Tangkapan Nelayan di Perairan Juata Kota Tarakan. Jurnal Harpodon Borneo. 6(1): 37-42.

Sarwono J. 2006. Metode Penelitian Kuantitatifdan Kualitatif. Yogyakarta: Ghara Ilmu.

Sumiono B, Ernawati T, Wedjatmiko. 2010. Analisis Penangkapan Ikan Kakap Merah (Lutjanus spp.) dan Kerapu (Epinephelus sp.) di Perairan Barru, Sulawesi Selatan. Jurnal Kebijakan Indonesia. 2(2): 101-112.

Tadjuddah $\mathrm{M}$, Wiryawan $\mathrm{B}$, Purbayanto A, Wiyono ES. 2013. Parameter Biologi Ikan Kerapu (Epinephelus sp.) Hasil Tangkapan di Perairan Taman Nasional Wakatobi, Sulawesi Tenggara Indonesia. Marine Fisheries. 4(1): 11-21.

Wahyuningsih, Prihatiningsih, Ernawati T. 2013. Parameter Populasi Ikan Kakap Merah (Lutjanus malabaricus) di Perairan Laut Jawa Bagian Timur. Jurnal Bawal. 5(3): 175-179. 